\title{
Terrorism in Africa: The Rise of Islamist Extremism and Jihadism
}

\author{
HAYAT ALVI*
}

ABSTRACT Africa is the springboard for al-Qaeda's global terrorism in modern history. The U.S. Embassy bombings in Dar es Salaam, Tanzania, and Nairobi, Kenya in August 1998 put al-Qaeda on the map and led to major counter-terrorism operations throughout parts of Africa. Bin Laden made a strategic decision to use Africa as a launching pad for al-Qaeda's global network and appeal. The linkages of Jihadist terrorism in Africa trace back to the fight against the Soviets in Afghanistan. Today, al-Qaeda and ISIS continue to use Africa as an important locale of operations. If improvements in human security, economies, politics, education, conflict resolution, and wealth distribution are not addressed, then the continent will continue to experience history repeating itself involving Jihadist terrorism in Africa.

\section{Introduction ${ }^{1}$}

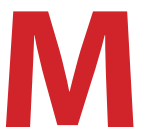
ajor developments in the Middle East, South Asia, and Cold War politics have led to al-Qaeda strategically using Africa as the springboard for its global "Jihadist"-based violence in the post-Cold War era. ${ }^{2}$ The U.S. Embassy bombings in Dar es Salaam, Tanzania, and Nairobi, Kenya on August 7, 1998 put al-Qaeda on the map in the most sinister way. The attacks killed more than 250 people and injured hundreds. The bombings brought alQaeda and Osama bin Laden into the center of the West's radar. Most of the victims of the embassy bombings were African and Muslim civilians.

This paper presents the details of al-Qaeda and related violent Jihadist groups' exploitation of African "safe havens" from which al-Qaeda has launched regional and global operations. Since the early 1990s until today, al-Qaeda and its ideological offspring, such as the ISIS, have come full circle from and to the continent of Africa. In addition, the definitions, terms, concepts, and ideologies pertaining to al-Qaeda, Jihadism, and violent Islamist extremism are explained. The thesis of this paper posits that, due to mostly conflict-related

* U.S. Naval War College, U.S. 
While many Salafists didn't agree with some of Riyadh's policies, its historical role as the birthplace of Salafism and its financial role as the patron underwriting the global spread of Salafist thought kept the movement within the Saudi orbit human and physical security deficiencies along with repressive governments in parts of Africa, which present violent extremist organizations (VEOs) with socalled soft targets, al-Qaeda and related groups have been able to operate from safe havens and launch their regional and global operations mostly with impunity. Therefore, good governance with simultaneous human security improvement is imperative. These factors presuppose that conflicts are resolved ensuring peace and justice for the long term.

It is important to define terrorism in Africa within specific contexts of pivotal events in modern history. The nature of terrorism that constitutes the focus of the study is al-Qaeda-affiliated groups, Boko Haram in Nigeria, al-Shabaab in Somalia, and most recently the ISIS, which broke away from al-Qaeda Central and set up cells in Libya and northern Sinai. The specific contexts are: postCold War, post-9/11 attacks, post-Libya campaign in 2011, and post-rise of ISIS in 2014.

Before engaging in deep analysis of terrorism in Africa, the concept of "terrorism" has to be defined and addressed. In this paper, terrorism is treated as the overarching concept under which a number of categories exist, such as "Islamist extremism," "violent Jihadism," and "violent extremist organizations;" the latter of which is the standard terminology that the U.S. government agencies utilize to describe organizations that embrace violent extremist ideologies. These ideologies serve the basis for violent operations that such organizations like al-Qaeda operationalize for specific geopolitical, socio-cultural, and ideological agendas as they interpret and apply them. Moreover, terrorism and its categories of Islamist extremism and violent Jihadism tend to target both combatants and non-combatants alike, hence civilians are often targeted and/or suffer as by-standers.

Generally, the term "terrorism" is controversial and often a normative concept. Therefore, the word terrorism is difficult to define, but the United Nations as well as law enforcement, security, intelligence, and counter-terrorism organizations have attempted to construct a conventional description of terrorism. For example, the United States Federal Bureau of Investigation (FBI) defines terrorism according to two contexts: (i) international terrorism -perpetrated by individuals and/or groups inspired by or associated with designated foreign terrorist organizations or nations (state-sponsored); (ii) domestic terrorism perpetrated by individuals and/or groups inspired by or associated with pri- 
marily U.S.-based movements that espouse extremist ideologies of a political, religious, social, racial, or environmental nature. ${ }^{3}$

The United Nations (UN) has a customary definition of terrorism, while, at the same time, emphasizing the difficulties in defining the term particularly in a universal context. According to the UN,

a customary rule of international law regarding the international crime of terrorism, at least in time of peace, has indeed emerged. This customary rule requires the following three key elements: (i) the perpetration of a criminal act (such as murder, kidnapping, hostage-taking, arson, and so on), or threatening such an act; (ii) the intent to spread fear among the population (which would generally entail the creation of public danger) or directly or indirectly coerce a national or international authority to take some action, or to refrain from taking it; (iii) when the act involves a transnational element. (Interlocutory Decision, 2011, para. 85). ${ }^{4}$

At the same time, the United Nations recognizes the challenges stemming from the absence of a universal definition of terrorism, saying that,

The implications of the absence of a universal definition of terrorism for legal purposes are wide-ranging. One is that the lack of a definition may facilitate the politicization and misuse of the term 'terrorism' to curb non-terrorist (or sometimes even non-criminal) activities. In turn, this can result in States, e.g., violating the rights of their own or other States' citizens, such as those of international human rights law, in the course of their counter-terrorism efforts.... Following the 9/11 terrorist attacks, the [UN] Security Council adopted Resolution 1373 (2001), which required States to take effective national legislative action as part of their global efforts to counter terrorism more effectively. Although, on the one hand, this obligated States to take legislative action, in the absence of a universally agreed definition of terrorism, the result has been a mixed legislative response and approach by Member States, sometimes with the potential to hinder rather than facilitate international cooperation. ${ }^{5}$

The term "Jihad" is equally controversial, but Islamist extremist groups have exploited the term to justify their violence. Jihad is an Arabic word meaning "to struggle, to strive" in the context of improving oneself to be more pious and righteous. However, it also has the meaning, "holy war," and the person who engages in the fight is called a "mujahid," the plural of which is "mujahideen." Hence, we get the term "freedom fighters" during the fight against the Soviets in Afghanistan, ${ }^{7}$ and then once the global violent Jihadist networks emerged mainly under the banner of al-Qaeda, the common term to describe them now is "Jihadists," and "violent extremist organizations," or VEOs. "Jihadism" is the principal term used for the violent ideologies that these VEOs promote 
Although it appears that violent Jihadism is proliferating throughout the African continent, one of the pivotal evolutionary stages of "Jihadism" in Africa traces back to the end of the Cold War under the banner of their narrow interpretation of the word "Jihad."

Most Jihadist ideologies follow an ultra-orthodox Sunni interpretation of Islam that can be described as "radical" or "extremist" in nature and implementation. While comparable Shia extremism exists as well, the vast majority of al-Qaeda-type Jihadist organizations have been Sunni, and, in fact, embrace Salafism. The concept of Salafism, which means "antecedent," is based on the belief that the "true" and "ideal" interpretation of Islam is found in the time of the Prophet Muhammad in the $7^{\text {th }}$ century AD. Thus, Salafists promote the idea of replicating Islamic society of the Prophet's $7^{\text {th }}$ century prototype of the "Islamic State" in today's world. That requires applying "not just the 'spirit' but [the] 'letter' of the law, which is what sets [Salafists] apart from their mainstream counterparts." ${ }^{8}$ Some Salafists embrace violent Jihadism. Salafism was at odds with the concept of jihadism -itself a violent offshoot of Salafism- as practiced by groups such as al-Qaeda that sought to use force to manifest their Islamist ideology. The Salafist movement could also afford to stay away from political activism in large part because it had a political backer in the government of Saudi Arabia. While many Salafists didn't agree with some of Riyadh's policies, its historical role as the birthplace of Salafism and its financial role as the patron underwriting the global spread of Salafist thought kept the movement within the Saudi orbit. Following the 9/11 attacks, Salafism rapidly spread throughout the Middle East and North Africa (MENA) region and Salafists organized more effectively and began to run charitable organizations and social relief groups. ${ }^{9}$

In turn, Jihadism is "the idea that jihad (religiously-sanctioned warfare) is an individual obligation (fard 'ayn) incumbent upon all Muslims, rather than a collective obligation carried out by legitimate representatives of the Muslim community (fard kifaya), as it was traditionally understood in the pre-modern era. They are able to do this by arguing that Muslim leaders today are illegitimate and do not command the authority to ordain justified violence. In the absence of such authority, they argue, every able-bodied Muslim should take up the mantle of jihad." ${ }^{10}$ As a result, Islamist/Salafist-based violent extremism has driven the contemporary global Jihadist movements and operations. The global Jihadist movements base their actions on what they view as a "Just War" paradigm according to their respective interpretations and frustrations pertaining to foreign and domestic policies of governments that they deem hostile to (Salafist) Islam and its principles. 
These realities have led governments to strengthen counter-terrorism measures, including in Africa. Western powers have provided training, intelligence, supplies, equipment, and military advice for counter-terrorism efforts in Africa. Generally, the security cooperation involving these strategies and tactics has targeted al-Qaeda in the Islamic Maghreb (AQIM) and other al-Qaeda-affiliated cells; Boko Haram in Nigeria; al-Shabaab in Somalia; and ISIS cells in Libya and northern Sinai, Egypt. Recent fronts in the counter-terrorism battles have been in the Sahel, Mali, Burkina Faso, Niger, Uganda, Kenya, Côte d'Ivoire, and Cameroon. ${ }^{11}$ Although it appears that violent Jihadism is proliferating throughout the African continent, and even has a dark hand in wildlife poaching and various types of illicit trafficking for sources of revenue, one of the pivotal evolutionary stages of "Jihadism" in Africa traces back to the end of the Cold War.

This is not to say that other brands of "Jihadism" have not existed in Africa prior to these critical stages of history. In fact, Egypt has a long history of suffering from extremism Islamic Jihad or Islamic Group (al-Jama'a al-Islamiyya), which is responsible for the 1981 assassination of Anwar al-Sadat. Moreover, another extremist network wreaked havoc during the civil war in Algeria (1992-1998). The Islamic Salvation Front (FIS) won the 1992 elections, prompting the military to intervene in politics, canceling parliamentary elections, and banning the FIS. The military arrested the FIS leaders and "responded with brutality, leading the country to civil war." ${ }^{\prime 2}$

The anti-government rebellion led by the violent Islamist insurgent group, FIS, "splintered into loosely affiliated armed groups with no discernible central command: including the Mouvement pour un État Islamique (MEI), Groupe Islamique Armé (GIA), Front Islamique du Djihad Armé (FIDA), the FIS-sponsored Armée Islamique du Salut (AIS), Ligue Islamique pour le Da'wa et le Djihad (LIDD), Groupe Salafiste pour la Prédication et le Combat (GSPC) and Houmat Al-Da'wa al-Salafiyya (HDS), among others."13 The GIA, in particular, carried out "indiscriminate attacks against civilians, abducted and killed foreigners, planted bombs in public spaces and committed massacres across the countryside. In 1995, the GIA declared all Algerians to be takfir, or apostates." 14 Their "Jihad" focused on the Algerian military and coup-supported government, hence this brand of Jihadism remained limited to the national level, rather than aspiring to expand regionally and internationally. However, the core concept of "Takfirism," which allows the Jihadist to brand a person or institution as an apostate -i.e., one who is no longer a "believer" in Islam- has become a widely-used tool of contemporary global Jihadism to justify violence against perceived enemies and non-conformists.

Again, these violent Jihadist organizations mostly focused on internal domestic politics and targeted their countries' regimes. They did not spill their vio- 


\section{Then U.S. Secretary of State Madeleine Albright looks at the damage caused by the al-Qaeda bombing of the U.S. Embassy in Dar es Salaam on August 7, 1998.

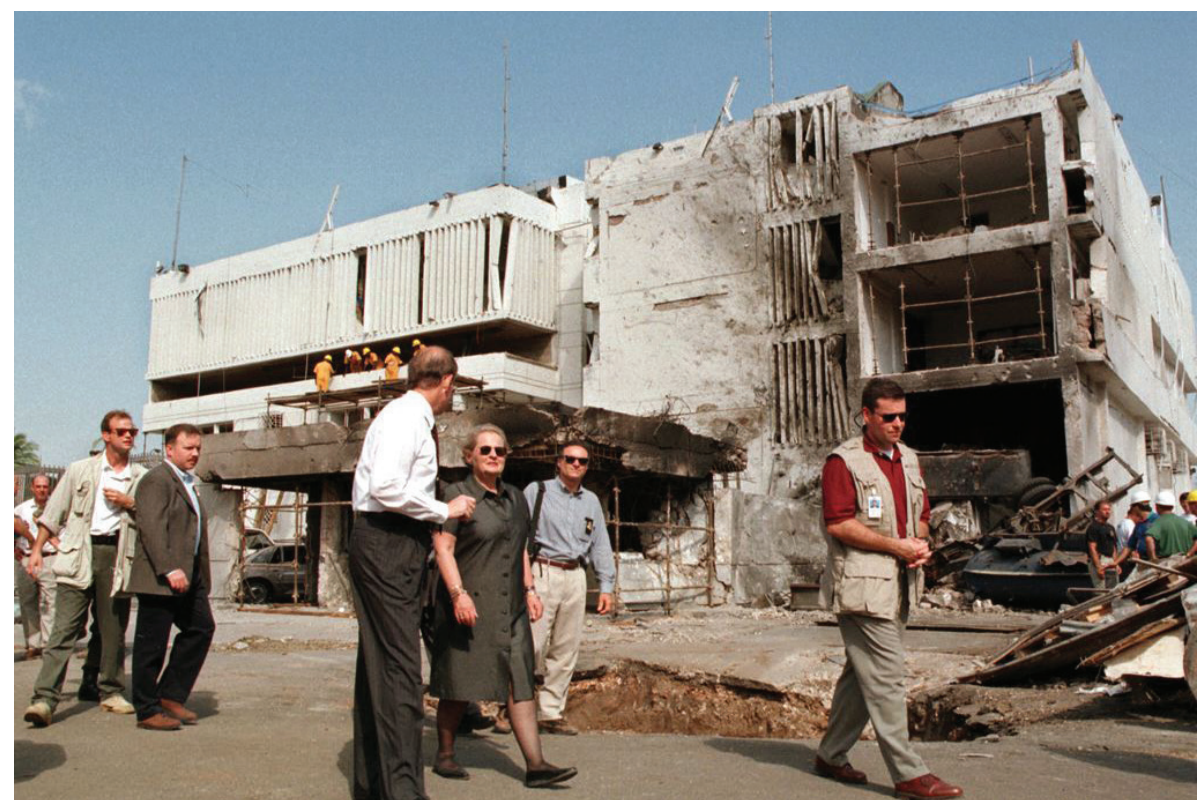

lent Jihadist activities outside of Egypt and Algeria, for the most part, in that time of history. That fact distinguishes them from the global Jihadist network of al-Qaeda, which, in addition to targeting specific regimes, expanded its network and activities across borders, regions, and even oceans. The latter also seeks to recruit globally under the banner of "Jihad."

What they all have in common is Salafism, or Salafi/Wahhabi ideology, which is ultra-orthodox, literalist, and inflexible in its interpretation of Islam. Therefore, violent extremists not only see non-Muslims as fair targets, but also Muslims who do not follow their creed. While the domestic events were unfolding in Algeria and Egypt, Osama bin Laden moved his operation to Sudan. The Soviets had pulled out of Afghanistan and the Afghan civil war was raging in the early 1990s. Bin Laden needed to formulate new goals and objectives for his new organization, al-Qaeda (The Base).

\section{Post-Cold War Seeds of Jihadism Are Planted in Africa}

When the Soviets withdrew from Afghanistan, the "Mujahideen" fighters who, with help from the United States, Pakistan, and Saudi Arabia, repelled the Soviets turned their guns against each other in what became the Afghan civil war. That was mostly the case with the Afghan militias vying for power. However, the "foreign" fighters who swelled the ranks of the Mujahideen militias came from all around the world. Many of them came from parts of North Africa, 
from predominantly Muslim countries like Algeria, Morocco, Tunisia, Libya, and Egypt. Palestinians, Jordanians, Syrians, Saudis, and some Turks also joined the ranks in Afghanistan. The status of the fight against the Soviet invaders had been deemed a "Jihad," or "holy war," which appealed to Muslims worldwide, including a wealthy Saudi named Osama bin Laden. Once the Mujahideen accomplished the mission of expelling the Soviets from Afghanistan, many foreign fighters returned to their respective home countries, while the Afghan militias engaged in the civil war.

Osama bin Laden turned his attention to forming his own organization. The impetus originates with the Iraqi leader, Saddam Hussein, invading Kuwait in August 1990, and the U.S.-led coalition response in the form of the 1991 Gulf War. Because Saudi Arabia, the birthplace of Islam with the holy places of Mecca and Medina located within its borders, decided to allow Western troops to set up bases on their land, Bin Laden was enraged. His top grievance has been the Saudi decision to allow foreign troops on Saudi land, which, in his view, would defile and adulterate the sacred sites and offend the religious and cultural sensitivities therein.

Bin Laden offered his services to Saudi Arabia to fight against Saddam Hussein and defend the holy lands, but the kingdom refused and chose the Western troops instead. Infuriated, bin Laden moved from the Afghan-Pakistan border region to Sudan. "In or about 1991, the leadership of al-Qaeda, including its 'emir' (or prince) Usama Bin Laden, relocated to the Sudan. Al-Qaeda was headquartered in Sudan from approximately 1991 until approximately 1996 but still maintained offices in various parts of the world. In 1996, Usama Bin Laden and other members of al-Qaeda relocated to Afghanistan. At all relevant times, al-Qaeda was led by its emir, Usama Bin Laden. Members of alQaeda pledged an oath of allegiance (called a 'bay'ah') to Usama Bin Laden and al-Qaeda. Those who were suspected of collaborating against al-Qaeda were to be identified and killed." ${ }^{15}$

The shift in focus away from Afghanistan and Pakistan, and even the Middle East, led to a substantive strategic use of Africa as a new base of operations for al-Qaeda. Peter Pham explains the evolution of post-Cold War jihadism in Africa. During the President Clinton era,

Leading jihadist strategists speculated about the opportunities that the state fragility and other vulnerabilities of African states afforded them to establish 
cells, recruit members, obtain financing, and find targets as well as hiding places on the continent. Al-Qaeda's online magazine, Sada al-Jihad ('Echo of Jihad'), even published an article by one Abu Azzam al-Ansari entitled 'AlQaeda is Moving to Africa', in which the author asserted: 'There is no doubt that al-Qaeda and the holy warriors appreciate the significance of the African regions for the military campaigns against the Crusaders. Many people sense that this continent has not yet found its proper and expected role and the next stages of the conflict will see Africa as the battlefield. ${ }^{36}$

Abu Azzam highlighted al-Qaeda's advantages for shifting its operations to Africa, explaining that, among other factors, jihadism per se has,

already been spread within the Muslim communities of many African countries; the political and military weakness of African governments; the wide availability of weapons; the geographical position of Africa vis-à-vis international trade routes; the proximity to old conflicts against 'Jews and Crusaders' in the Middle East as well as new ones, where the author almost gleefully welcomed the possibility of Western intervention; the poverty of Africa which 'will enable the holy warriors to provide some finance and welfare, thus, posting there some of their influential operatives'; the technical and scientific skills that potential African recruits would bring to the jihadist cause; the presence of large Muslim communities, including ones already embroiled in local conflicts with Christians or adherents of traditional African religions; the links to Europe through North Africa 'which facilitates the move from there to carry out attacks'; and the fact that Africa has a wealth of natural resources, including hydrocarbons and other raw materials, which are 'very useful for the holy warriors in the intermediate and long term.'

Abu Azzam concluded with an unequivocal assessment:

In general, this continent has an immense significance. Whoever looks at Africa can see that it does not enjoy the interest, efforts, and activity it deserves in the war against the Crusaders. This is a continent with many potential advantages and exploiting this potential will greatly advance the jihad. It will promote achieving the expected targets of Jihad. Africa is a fertile soil for the advance of jihad and the jihadi cause. ${ }^{17}$

For Bin Laden, his simmering anger at the Saudis also encompassed hatred and anger towards the Americans and other Western powers. Africa lent a prime opportunity for al-Qaeda to target the United States by launching truck bombings of the U.S. embassies in Dar es Salaam, Tanzania and Nairobi, Kenya on August 7, 1998. Bin Laden "already escalated his rhetorical war against America the previous February, when he published a fatwa (religious edict), on behalf of a coalition of militant groups called The International 
Islamic Front for Jihad Against Jews and Crusaders." ${ }^{18}$ Choosing August 7, 1998 for the embassy attacks was also strategic and symbolic, because it marked,

the 8-year anniversary of the arrival of American troops in Saudi Arabia in response to Saddam Hussein's invasion of Kuwait. And the attack was executed in a manner that would soon come to characterize al-Qaeda operations. The trucks were both driven by suicide attackers and the bombs were delivered only a few minutes apart, beginning with the first blast in Nairobi at approximately 10:35 local time. Each of the truck bombs contained more than a ton of explosives. In Nairobi, the blast sheared off the face of the embassy and completely destroyed a neighboring seven-story office building that con-

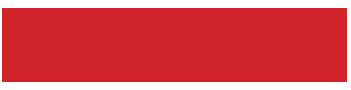

Boko Haram is a force to be reckoned with, even while it may be on its back foot. It is not worth the risk to take it lightly or assume that the threat has been eliminated. The same rings true for al-Qaeda in the Islamic Maghreb tained a secretarial college. The toll was 213 dead, among them 12 Americans. Hundreds of people were blinded by flying glass and it took rescuers two days to free all the people buried in the rubble and debris. ${ }^{19}$

President Clinton responded with thirteen Tomahawk cruise missiles to "destroy a pharmaceutical plant that was supposedly producing a chemical precursor for VX nerve agent. The plant instead turned out to be a legitimate factory that produced nearly half of Sudan's medicines and had no connection to Osama bin Laden." ${ }^{20}$ Similarly, the United States targeted Afghan camps presumed to be affiliated with Bin Laden. The United States launched 66 missiles, but "the missiles destroyed several buildings in the camp and killed six men, none of them al-Qaeda leaders. Many of the missiles exploded just across the border in Pakistan." ${ }^{21}$ Protestors held up placards in Sudan blaming the Monica Lewinsky sex scandal, ${ }^{22}$ claiming that the missile attacks were a diversionary tactic by President Clinton in order to repel domestic attention away from his troubles in Washington.

By the time the George W. Bush Administration took the seat in the White House, "national security officials were slow to realize how profoundly the threat of jihadi [terrorism] had grown and did not prioritize it appropriately at first. Consequently, the United States was still vulnerable to jihadi [terrorism] on September 11, 2001, more than three years after the East Africa Embassy bombings." 23

Undoubtedly, Bin Laden and al-Qaeda earned their first global "recognition" among violent Jihadists on African soil. The East Africa Embassy bombings indicate that the terrorist organization's geopolitical strategy for staging its op- 
erations in Africa following the Soviet withdrawal from Afghanistan and the 1991 Gulf War was a smart move. As al-Qaeda assessed, at the time parts of Africa provided the ideal vulnerable targets. Thereafter, Bin Laden and al-Qaeda's next major target would be the United States on September 11, 2001.

\section{Post-9/11 Attacks and Jihadism in Africa}

The East Africa Embassy bombings and the September 11, 2001 attacks in the United States led to two significant effects: first, these attacks provided a means of "marketing" al-Qaeda at the global level, which helped it in terms of recruitment and ideological sympathizers; second, it led to the United States to launch the "Global War on Terrorism" (GWOT), starting with the military campaigns against the Taliban and al-Qaeda in the Afghanistan-Pakistan border region, and the disastrous 2003 U.S. invasion of Iraq, which has been found to be wholly disconnected to the $9 / 11$ attacks.

During these stages leading into the $21^{\text {st }}$ century, and soon after, the African continent began to see major al-Qaeda-affiliated and modeled violent Jihadist organizations forming and causing mayhem. One such group has been Boko Haram in Nigeria.

\section{Boko Haram in Nigeria}

The Council on Foreign Relations describes Boko Haram as "a top-tier threat to Africa's most populous country. An insurgency led by the Islamist group has claimed tens of thousands of lives and displaced millions more in recent years. At times, the violence has spilled over Nigeria's borders into other countries in the Lake Chad Basin." ${ }^{24}$ Boko Haram, which loosely translated means "Western education is sinful," formed in 2002 as a result of "longstanding religious tensions, political corruption, and widening economic disparity in Nigeria. The government's heavy-handed police and counter-terrorism tactics are also fuel for the group's flame, analysts say." ${ }^{25}$ Mohammed Yusuf, "an influential Islamist cleric from Borno State," founded the terrorist group based in northeast Nigeria, originating in Maiduguri. The primary objective of Boko Haram is to establish an extremist fundamentalist Islamic state based on Islamic law (sharia) and a hardline Salafi interpretation and implementation of sharia. ${ }^{26}$ After its founding leader Mohammed Yusuf was killed, a new Boko Haram leader emerged, Abubakar Shekau. He has since perpetuated the northeast Nigerian insurgency, but also under his leadership, Boko Haram has spilled its operations across borders. The terrorist group has attacked markets, razed villages, pillaged, massacred civilians, and kidnapped hundreds of girls and women. The group routinely targets schools, living up to its name. In April 2014, Boko Haram kidnapped 276 female students from the town of Chibok. The victims came to be known as the "Chibok girls." 27 
Since its emergence, Boko Haram has splintered into various factions, and for a long time it remained affiliated with al-Qaeda in the Islamic Maghreb (AQIM), which in turn has links to al-Qaeda Central. In 2014, Shekau declared a "Caliphate" in northeastern Nigeria. ${ }^{28}$ Upon breaking into factions, Shekau's breakaway group pledged allegiance to ISIS in 2015, "rebranding itself as numerous times, but even recently his video has emerged indicating that he is still alive and active in leading his faction. Boko Haram is a major thorn in the side of not only Nigeria, but also its neighboring countries. This group has been the main reason for Chad, Niger, Cameroon, among others to undertake significant counter-terrorism training and operations. Boko Haram is a force to be reckoned with, even while it may be on its back foot. It is not worth the risk to take it lightly or assume that the threat has been eliminated. The same rings true for al-Qaeda in the Islamic Maghreb.

\section{Al-Qaeda in the Islamic Maghreb}

Al-Qaeda in the Islamic Maghreb is a "Salafi-Jihadist militant group and U.S.-designated foreign terrorist organization (FTO) operating in the Sahara and Sahel." ${ }^{30}$ Its origins are directly linked to Algeria's civil war in the 1990s, specifically the GIA, and as "the primary transnational terror threat" pose a menace to West and North Africa. ${ }^{31}$ According to the Council on Foreign Relations,

In 1998, several GIA commanders grew concerned that brutal tactics, such as beheadings, were alienating their Algerian constituency and broke away to found the Salafist Group for Preaching and Combat (GSPC). GIA, now defunct, was delisted as an FTO in 2010. GSPC initially drew popular support by vowing to continue the rebellion without killing civilians, but a government amnesty and counter-terrorism campaign drove it into disarray in the early 2000s. The group aligned with al-Qaeda in the 2000s to stage high-profile attacks and improve recruiting and fundraising, analysts say. Ayman al-Zawahiri, al-Qaeda's leader, who was at the time second in command, announced the union on September 11, 2006, and GSPC rebranded itself as AQIM the following January. ${ }^{32}$

Analysts contend that the top leadership of AQIM originates in the fight against the Soviets in Afghanistan. A number of them fought alongside Bin Laden in Afghanistan, and then "returned to the Middle East and North Af- 


\section{Given that the current U.S. administration of President Trump has cut funding for the Somalia mission, al-Shabaab is likely to take advantage of the military power gaps}

rica radicalized." 33 AQIM consists of sporadic cells and brigades, and its causes vary as well. Quoting former Chairman of the Joint Chiefs of Staff General Martin Dempsey, AQIM is "a syndicate of groups who come together episodically, when it's convenient to them, in order to advance their cause. Sometimes their cause is terrorism. Sometimes it's criminal. Sometimes it's arms trafficking." ${ }^{34}$ GlobalSecurity.org describes AQIM as dissident groups who broke away to form "Movement for Unity and Jihad in West Africa (MUJAO) and al-Mulathamun Battalion and its subordinate unit al-Muwaqi'un Bil-Dima (Those Who Sign With Blood) led by former AQIM battalion leader Mokhtar Belmokhtar." ${ }^{35}$ The groups later formed al-Murabitun (The Sentinels). ${ }^{36}$ AQIM has provided the local-to-global linkages, using north and west Africa as its base of operations:

[AQIM] may be considered as a "glocal" group, a hybrid structure that weds both the local specifics and goals, to create a Maghrebian caliphate, and global operational methods. In the point of view of the comprehension of jihadi groups, this approach of both local and global has in all cases numerous advantages: this permits one to avoid the syndrome of labeling what are often local and specific attacks as simply "al-Qaeda." On the other hand, it also refocuses on the specificity of local violence and individuals. This "glocal" approach may deserve examination of other jihad groups. Observers have highlighted the transformation of the Algerian Salafist Group for Preaching and Combat (known by its French name, Groupe Salafiste pour la predication et le combat-GSPC) into al-Qaeda in Islamic Maghreb. Although research has concluded that the al-Qaeda in Islamic Maghreb is a manifestation of the continuing strength of Osama bin Laden's global organization, its current research on terrorist groups has sometimes neglected to analyze this double phenomenon of global and local roots. ${ }^{37}$

Belmokhtar, a "one-eyed veteran of the anti-Soviet Afghan insurgency, is believed to have masterminded the January 2013 hostage crisis at a natural-gas facility in eastern Algeria that left at least 38 civilians dead, as well as twin suicide bombings in Niger that killed at least 26 in May of that year." ${ }^{38}$ Like Boko Haram's Shekau, Belmokhtar has supposedly been killed numerous times, but repeatedly re-emerges in media messages to claim that he is alive and still leading the group. AQIM is known for kidnapping especially foreigners and holding hostages for ransom. The terrorist group is also known for its hatred 


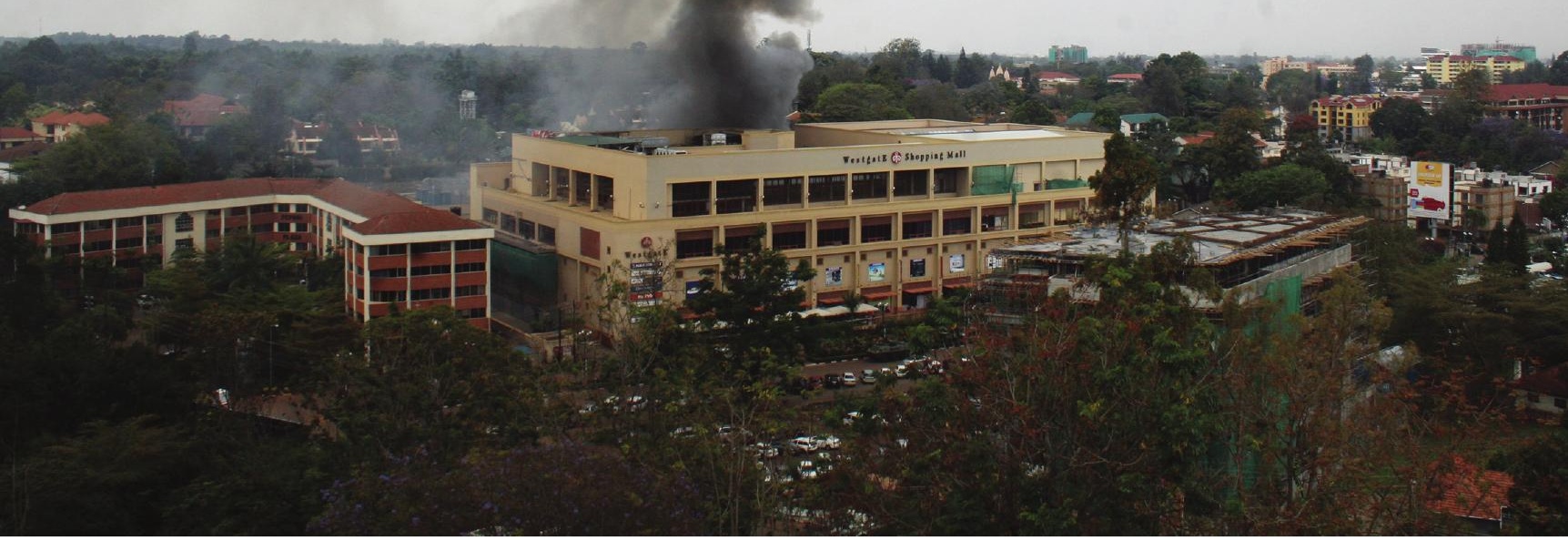

of France and French activities in the region of western Africa. Hence, AQIM regularly targets French troops and civilians.

The eastern part of Africa has not been immune to al-Qaeda-affiliated Jihadism. Somalia and its neighbors have been afflicted with al-Shabaab violent Jihadism and the flow of refugees stemming from it.

\section{Al-Shabaab in Somalia: Al-Qaeda's Foot Soldiers in East Africa}

Somalia has suffered from civil strife since the 1980s and it has seen Western intervention, the rise of piracy, human security disasters, famines, and endless proliferation of warlords and militias. Within such matrices, the violent extremist/Jihadist group al-Shabaab (The Youth) has risen as a formidable challenge to Somalia's stability and security, has recruited from as far away as the Britain and the United States, has remained loyally affiliated with al-Qaeda Central, has inspired some "homegrown terrorism" in the West, and has carried out some of the most violent crimes and punishments against civilians and those it deems as violators of its version of Islamic law, including amputations and stoning. Al-Shabaab "advocates the Saudi-inspired Wahhabi version of Islam, while most Somalis are Sufis" ${ }^{39}$ (Islamic mystics).

Al-Shabaab "emerged as the radical youth wing of Somalia's non-defunct Union of Islamic Courts, which controlled Mogadishu in 2006, before being forced out by Ethiopian forces. There are numerous reports of foreign jihadists 
going to Somalia to help al-Shabaab, from neighboring countries, as well as the U.S. and Europe." 40

Al-Shabaab may have sought to hook up with Boko Haram and AQIM in collaborative efforts for common goals and agendas. In January 2014, al-Shabaab "debated whether to switch allegiance to the IS group after it emerged, [but] it eventually rejected the idea, resulting in a small faction breaking away." ${ }^{41}$ Therefore, the core al-Shabaab group can be considered the "foot soldiers" of al-Qaeda Central in East Africa.

Al-Shabaab is responsible for a long list of terrorist attacks, not only in Somalia, but also in Kenya and Uganda. In following the "Mumbai Attacks" model, in 2013, al-Shabaab carried out a massacre at the Westgate Shopping Mall in Nairobi, laying siege to the building and killing 67 civilians. In 2010, alShabaab "bombed a rugby club and a restaurant in Uganda's capital Kampala, killing 74 people watching [the football World Cup final between Spain and the Netherlands]. ${ }^{42}$ Moreover, al-Shabaab confirmed,

carrying out a massive attack on a Kenyan military base in Somalia's el-Ade town in January 2016, killing, according to Somalia’s then-President Hassan Sheikh Mohamud, about 180 soldiers. The Kenyan military disputed the number, but refused to give a death toll. It has also staged several attacks in Kenya, including the 2015 massacre at Kenya's Garissa University, near the border with Somalia. A total of 148 people died when gunmen stormed the university at dawn and targeted Christian students. ${ }^{43}$

The African Union (AU) and U.S. troops have long targeted al-Shabaab in Somalia with counter-terrorism tactics. According to the United States Africa Command (AFRICOM), "The U.S. response to the challenges in Somalia has been to work with the Federal Government and the Federal Member state administrations, in coordination with the African Union, the United Nations, and other partners working toward a common goal: to support Somali-led efforts to stabilize and rebuild their country along democratic and federal lines." ${ }^{4}$ AFRICOM points out that its efforts are "in conjunction with Somali National Security Forces, and are providing direct support to the five primary troop contributing countries in the African Union Mission in Somalia, also known as AMISON: Uganda, Kenya, Burundi, Djibouti, and Ethiopia." ${ }^{45}$ AFRICOM works with "the United Nations, the European Union, and a range of traditional and non-traditional partners including the United Kingdom, Turkey, and the United Arab Emirates." ${ }^{46}$

Al-Shabaab has been cornered and defeated many times in Somalia, but it has managed to survive and even regroup repeatedly. Given that the current U.S. administration of President Trump has cut funding for the Somalia mission, 
al-Shabaab is likely to take advantage of the military power gaps.

Two major events, one in Libya and the other in Iraq and Syria, have brought al-Qaeda-affiliated Jihadism in Africa to full circle, albeit in different contexts but with parallel players and ideologies. These two major events have affected Boko Haram, AQIM, al-Shabaab, and other Jihadist organizations in Africa. The first major event is the 2011 anti-Qaddafi U.S.-led NATO military campaign in Libya and its aftermath. The second major event is the rise of ISIS in Syria and Iraq in 2013-2014, which forced various al-Qaeda cells in Africa, and worldwide, to make decisive pledges to either remain in the al-Qaeda orbit, or to join the newer, more violent and extremist ISIS.
The rise of ISIS links the al-Qaeda metamorphoses from the 1990s in Africa to the insurgency against U.S. troops in Iraq following the 2003 invasion, to the 2011 "Arab Spring" uprisings and revolutions and its impacts on the outbreak of the Syrian civil war to full circle in Africa again

\section{The 2011 Libya Campaign}

In late 2010 and early 2011, the "Arab Spring" uprisings and revolutions gripped the Middle East and North Africa (MENA), beginning in Tunisia, where the protest movement overthrew the dictator Zine al-Abidine Ben Ali. Libya and Egypt experienced the domino effects of the events in Tunisia. When Libya's Colonel Muammar Qaddafi responded violently to the Benghazi uprisings, which later spread to Tripoli and elsewhere, Libyan activists pleaded with Western powers to protect them from Qaddafi's wrath. Mainly, the activists called for air cover because Qaddafi was unleashing fighter jets against the ragtag militias and civilians on the ground.

The United Nations passed UN Security Council Resolution 1973, which states that the international community bears a "Responsibility to Protect" (R2P) Libyan civilians from "genocide" at the hands of Qaddafi's security forces. Following this UN resolution, the United States and NATO patrolled a "no-fly zone" in Libyan airspace in late March 2011. Then, on March 31, 2011, NATO began "Operation Unified Protector," encompassing a bombing campaign of mainly the capital Tripoli. By late August 2011, the rebel militias made significant advances, and Qaddafi went into hiding. On October 20, 2011, Qaddafi was discovered and killed.

Since then, the impacts of the 2011 Libya War have been multifaceted, involving tremendous flows of arms, people, trafficking of goods and people, and ma- 
If the patterns since the postCold War era hold true, the world is likely to see future iterations of ISIS and al-Qaedaaffiliated violent Jihadist groups persisting in various parts of Africa, particularly in the north, east, west, Sahel region, and as far as central Africa jor breaches of the Libyan-Tunisian, Libyan-Egyptian, Libyan-Chadian, and Libyan-Niger borders. These breaches have negatively affected the national security of said countries, especially since countless "Jihadists" fighting in Libya, as well as new recruits heading to AQIM and other al-Qaeda-affiliated cells, poured into Mali, Mauritania, Niger, Nigeria, Burkina Faso, Cameroon, and even the Central African Republic (CAR) when the genocidal violence took place there in 2013-2014. Along with terrorists, there have been weapons crossing borders and the arms trade is still flourishing in the region.

Warning about the possibility of the CAR collapsing into failed state status, Daniel Wagner says,

The CAR may become a template for radical political change in Africa, with militant Islamist extremists gaining greater power throughout the central part of the continent. If that were to occur, the CAR would become a magnet for extremists and a hub for non-state actors - in essence, the Pakistan of Africa, where porous borders and ungovernable terrain make the country a haven for a range of militant jihadists... It is certainly possible that al-Qaeda will emerge to become the dominant force in the CAR, and that it will metastasize to surrounding states. ${ }^{47}$

The fallout and unintended consequences stemming from the 2011 Libya War are profound. Several years following the NATO campaign, there are still ripple effects throughout the region, reaching as far as Central Africa. Citing a UN Security Council's Group of Experts report, Reuters reports that the spread of weapons from Libya are happening "at an alarming rate, fueling conflicts in Mali, Syria and elsewhere and boosting the arsenals of extremists and criminals in the region... The North African state had become a key source of weapons in the region as its nascent government struggles to exert authority." 48

Libyan government security forces remain weak and militias, made up of former rebel fighters, hold power on the ground. "Cases, both proven and under investigation, of illicit transfers from Libya in violation of the [arms] embargo cover more than 12 countries and include heavy and light weapons, includ- 
ing man-portable air defense systems, small arms and related ammunition and explosives and mines," the experts wrote in the report. "Illicit flows from the country are fueling existing conflicts in Africa and the Levant and enriching the arsenals of a range of non-State actors, including terrorist groups," according to the 94-page report ... "The proliferation of weapons from Libya continues at an alarming rate," the report said. ${ }^{49}$

In fact, many terrorists and weapons can be traced from Libya to the al-Qaeda cell -which later pledged allegiance to Abu Bakr al-Baghdadi, the leader of ISIS- in the northern Sinai region of Egypt. Similarly, Tunisia is afflicted with the Libyan-Tunisian porous border, which has led to some terrorist attacks by ISIS in Tunisia. Then, in 2014 and 2015 there are the grotesque videos of ISIS beheadings of 21 Egyptian Coptic Christian laborers and in a different setting 30 Ethiopian Christians in Libya, indicating that by then ISIS was working towards setting up a new operations center in Libya. Moreover, ISIS in Sinai is particularly troubling not only to Egypt, but also to Israel. Zvi Mazel corroborates the linkages between ISIS in Egypt and the arms flows from Libya:

ISIS owes its continued success to the ease with which it keeps acquiring superior weapons, morphing "from a small organization with light armament to something close to a regular militia with sophisticated armament and a firepower to be reckoned with." In the chaos following the Libyan civil war in the years 2011-2013, huge stockpiles of the Libyan Army were up for grabs. Soon a steady stream was being smuggled by a new jihadi group, Ansar al-Sharia, which appeared in the eastern part of the country even before the killing of Muhammad Gaddafi. Some of its leaders became members of the Interim Transitional National Council that ruled the country, which gave them legitimate access to army depots. It had links with al-Qaeda in the Islamic Maghreb, very active in North Africa and Sahel countries, and some of the weapons found their way there; but the greater part went to Egypt, then in a state of turmoil, and reached terrorist organizations in the Sinai Peninsula and in Gaza. ${ }^{50}$

Al-Qaeda's nascent operations in the African continent during the 1990s also have linkages to the rise of ISIS in Syria and Iraq in 2013-2014. Because ISIS is a breakaway group from al-Qaeda in Syria, at the time called the Nusra Front, the overall connections between ISIS and al-Qaeda at a foundational level should not be lost.

\section{The Rise of ISIS}

The rise of ISIS links the al-Qaeda metamorphoses from the 1990s in Africa to the insurgency against U.S. troops in Iraq following the 2003 invasion, to 
As long as wars, conflicts, and failing or failed states provide power vacuums and safe havens for the likes of al-Qaeda and ISIS in Africa, the probability of their proliferation and mutations reemerging and causing violent chaos is, unfortunately, quite high the 2011 "Arab Spring" uprisings and revolutions and its impacts on the outbreak of the Syrian civil war to full circle in Africa again. This is because at the peak of ISIS' success countless global al-Qaeda cells decided to pledge allegiance to ISIS leader al-Baghdadi. Among these al-Qaeda cells and affiliates in Africa who pledged allegiance to ISIS is Boko Haram under Shekau, and the ISIS cell called "Sinai Province" in Egypt. Al-Shabaab split into a group that has remained loyal to al-Qaeda Central, and another off-

shoot group that has pledged allegiance to ISIS. AQIM remains unchanged regarding its allegiance.

Another major development bringing al-Qaeda's evolutionary process and iterations full circle to Africa is the decision of ISIS to set up a potent cell in Libya, which the United States and other Western powers are targeting in counter-terrorism campaigns even today. According to Frederic Wehrey in The Atlantic,

As U.S. military forces hunt down the remnants of the Islamic State in Syria and Iraq, they are also waging a quieter campaign in the fractured country of Libya. Conducted primarily from the air and through special-operations personnel based in the western city of Misrata, the effort aims to eradicate cells of fighters who fled the group's stronghold in the central city of Sirte before its fall to Libyan forces in December 2016. According to Libyan officials I spoke with in December, these cells number around 500. They include capable leaders and planners who comprise what ISIS calls its 'Desert Brigade' and its 'Office of Borders and Immigration,' a section responsible for external operations, logistics, and recruitment. Moving along the shallow valleys south of Sirte, the network has already conducted a number of attacks on checkpoints and convoys and, most recently, against an oilfield. It is also reconstituting itself. A burly 38year old jihadist from the Libyan town of Bani Walid named Malik al-Khazmi reportedly helps lead the recruitment drive. Libyan officials believe he played a pivotal role in the rise of ISIS in Libya. ${ }^{51}$

If the patterns since the post-Cold War era hold true, the world is likely to see future iterations of ISIS and al-Qaeda-affiliated violent Jihadist groups persisting in various parts of Africa, particularly in the north, east, west, Sahel region, and as far as central Africa. These patterns reflect ideological competition be- 
tween and within groups, governments, civilians, non-state actors, military and security organizations, and intra- and extra-regional (to Africa) powers, including the United States. This all began with the efforts to fight against the Soviets in Afghanistan. Since the Afghanistan mission ended, the outflow of terrorist groups and violent extremist Salafist ideologies fervently established a foothold in Africa. This has been a strategic move that has ripple effects that are evident today.

\section{Conclusion}

Connecting the dots of the post-Cold War transnational violent Jihadist networks, groups, and activities has significant meeting points in Africa. Peter Pham reminds us that,

The challenge of [terrorism] in Africa cannot be addressed except in an integrated fashion, with solutions that embrace a broader notion of human security writ large -encompassing social, economic, and political developmentwhich, often enough, also must transcend the continent's national and other artificial boundaries. $^{52}$

As long as wars, conflicts, and failing or failed states provide power vacuums and safe havens for the likes of al-Qaeda and ISIS in Africa, the probability of their proliferation and mutations reemerging and causing violent chaos is, unfortunately, quite high. The cycle of human security crises that are conflict-related, as well as climate and natural disaster-caused, throughout parts of Africa adds to the misfortune and miseries of locking civilians in the pervasive cycle of suffering and being violently subjugated at the hands of violent Jihadist organizations.

Jackie Cilliers emphasizes the dangers of human security deficiencies in Africa, as the thesis of this paper has highlighted, contending that, "Eventually, good governance in Africa, a respect for institutions, as opposed to individuals, and inclusive economic growth will prove to be the best defense against radicalization, as will respect for the rule of law and functioning criminal-justice systems." ${ }^{33}$ The thesis of this paper has illustrated the linkages between the human security and governance related variables and potentials for "radicalization," which could lead to violent extremist actions of Jihadist-oriented groups and individuals. Cilliers substantiates this, saying that, "Although [terrorism] is not necessarily caused by socio-economic problems, there is a clear correlation between relative deprivation (the awareness and politicization of absolute deprivation) and radicalism." ${ }^{54}$ Failing and failed states "are unable to provide adequate social and economic services, and grassroots [Islamic] organizations step into this vacuum to provide goods and services in crucial 
areas, such as healthcare, education, and housing. In doing so, they magnify the weakness of the state and open the field for the rise of Islamic networks with their own political agendas; ... repressive political systems exacerbate these dynamics." 55

Cases exemplifying these weak states and/or poor governance and policies include Algeria, Egypt, Somalia, Nigeria, and most recently Libya. Counter-terrorism efforts that do not take the human security and quality of life factors into account are likely fruitless, as the cycle of violence and counter-violence will perpetuate indefinitely. In order to fight against these trends, improvements in human security, economic health, political development, education, and basic security are desperately needed. Failure to do so will result in history repeating itself, albeit in different contexts, when it comes to extremist-based violent Jihadism in Africa.

\section{Endnotes}

1. The views expressed in this paper are those of the authors and are not an official policy or position of the U.S. Naval War College, the Department of Defense, or the U.S. Government.

2. A number of sources substantiate this: Jackie Cilliers, "Violent Islamist Extremism and Terror in Africa," Institute for Security Studies, (October 2015), retrieved from https://issafrica.org/research/papers/ violent-islamist-extremism-and-terror-in-africa, pp. 1-31; Laurence Wright, The Looming Tower: Al Qaeda and the Road to 9/11, (New York: Vintage Books, 2006); "Bitter Rivals," documentary film, Frontline PBS, (February 20, 2018), retrieved from www.pbs.org/wgbh/frontline/film/bitter-rivals-Iranand-Saudi-Arabia.

3. "Terrorism Definitions," Federal Bureau of Investigation (FBI), (2018), retrieved from https://www.fbi. gov/investigate/terrorism.

4. "Defining Terrorism," UN Office on Drugs and Crime (UNODC), (July 2018), retrieved from https://www. unodc.org/e4j/en/terrorism/module-4/key-issues/defining-terrorism.html.

5. "Defining Terrorism."

6. See, Hayat Alvi, "Hard and Soft Jihad in International Relations," Journal of Development Alternatives and Area Studies, Vol. 28, No. 2, 3, 4 (June, September, December 2009), p. 6.

7. See, George Crile, Charlie Wilson's War: The Extraordinary Story of How the Wildest Man in Congress and a Rogue CIA Agent Changed the History of Our Times, (New York: Grove Press, 2007).

8. Shadi Hamid and Rashid Dar, "Islamism, Salafism and Jihadism: A Primer," Brookings, (July 15, 2016), retrieved from https://www.brookings.edu/blog/markaz/2016/07/15/islamism-salafism-and-jihadisma-primer/.

9. Hayat Alvi, "The Diffusion of Intra-Islamic Violence and Terrorism: The Impact of the Proliferation of Salafi/Wahhabi Ideologies," Middle East Review of International Affairs (MERIA), Rubin Center, (July 17, 2014), retrieved from http://www.rubincenter.org/2014/07/the-diffusion-of-intra-islamic-violence-andterrorism-the-impact-of-the-proliferation-of-salafiwahhabi-ideologies/.

10. Alvi, "The Diffusion of Intra-Islamic Violence and Terrorism."

11. See, U.S. Africa Command's website: www.africom.mil.

12. "Algeria: Civil War - Mass Atrocity Endings," World Peace Foundation, (August 7, 2015), retrieved from https://sites.tufts.edu/atrocityendings/2015/08/07/72/.

13. "Algeria: Civil War - Mass Atrocity Endings." 
14. "Algeria: Civil War - Mass Atrocity Endings."

15. "Inside the Terror Network - Background: Al Qaeda," Frontline PBS, retrieved from https://www.pbs. org/wgbh/pages/frontline/shows/network/alqaeda/indictment.html.

16. J. Peter Pham, "20 Years after the Embassy Bombings: The Long War in Africa," Atlantic Council, (August 6, 2018), retrieved from http://www.atlanticcouncil.org/blogs/new-atlanticist/20-years-after-the-embassy-bombing.

17. Pham, "20 Years after the Embassy Bombings: The Long War in Africa."

18. Jeffrey William Lewis, "August 2018: The 1998 East African Embassy Bombings," Ohio State University (OSU), ORIGINS, (August 2018), retrieved from http://origins.osu.edu/milestones/august-2018-1998-east-african-embassy-bombings.

19. Lewis, "August 2018: The 1998 East African Embassy Bombings."

20. Lewis, "August 2018: The 1998 East African Embassy Bombings."

21. Lewis, "August 2018: The 1998 East African Embassy Bombings."

22. Lewis, "August 2018: The 1998 East African Embassy Bombings."

23. Lewis, "August 2018: The 1998 East African Embassy Bombings."

24. Claire Felter, "Nigeria's Battle with Boko Haram," Council on Foreign Relations (CFR), (August 8, 2018), retrieved from https://www.cfr.org/backgrounder/nigerias-battle-boko-haram.

25. Felter, “Nigeria's Battle with Boko Haram;"“'Hunting Boko Haram," Frontline PBS, (September 9, 2014), retrieved from https://www.pbs.org/wgbh/frontline/film/hunting-boko-haram/.

26. "Hunting Boko Haram," Frontline PBS.

27. BBC News has an extensive report by Alastair Leithead and Stephanie Hegarty, "The Fate of the Chibok Girls," BBC News, (May 19, 2017), retrieved from https://www.bbc.co.uk/news/resources/idt-sh/chibok_girls.

28. See, "Nigeria: The Fight against Boko Haram," France24, (September 14, 2018), retrieved from https:// www.france24.com/en/20180913-video-reporters-plus-fight-against-boko-haram-nigeria-maiduguri.

29. Felter, "Nigeria's Battle with Boko Haram."

30. Zachary Laub and Jonathan Masters, "Al-Qaeda in the Islamic Maghreb," Council on Foreign Relations (CFR), (March 27, 2015), retrieved from https://www.cfr.org/backgrounder/al-qaeda-islamic-maghreb.

31. Laub and Masters, "Al-Qaeda in the Islamic Maghreb."

32. Laub and Masters, "Al-Qaeda in the Islamic Maghreb."

33. Laub and Masters, "Al-Qaeda in the Islamic Maghreb."

34. Laub and Masters, "Al-Qaeda in the Islamic Maghreb."

35. "Al-Qaeda in the Land of the Islamic Maghreb (AQIM)," GlobalSecurity.org, (March 20, 2016), retrieved from https://www.globalsecurity.org/military/world/para/gspc.htm.

36. "Al-Qaeda in the Land of the Islamic Maghreb (AQIM)."

37. "AI-Qaeda in the Land of the Islamic Maghreb (AQIM)."

38. Laub and Master, "Al-Qaeda in the Islamic Maghreb."

39. "Who Are Somalia's al-Shabab?" BBC News, (December 22, 2017), retrieved from https://www.bbc. com/news/world-africa-15336689.

40. "Who Are Somalia's al-Shabab?"

41. "Who Are Somalia's al-Shabab?"

42. "Who Are Somalia's al-Shabab?"

43. "Who Are Somalia's al-Shabab?" 
44. U.S. Africa Command Public Affairs, "Why the U.S. Military Is in Somalia," AFRICOM, (November 29, 2017), retrieved from https://www.africom.mil/media-room/article/30125/why-the-u-s-military-is-insomalia.

45. U.S. Africa Command Public Affairs, "Why the U.S. Military Is in Somalia."

46. U.S. Africa Command Public Affairs, "Why the U.S. Military Is in Somalia."

47. Daniel Wagner, "Al-Qaeda's Growing Influence in Central Africa," Huffington Post, (May 30, 2014), retrieved from https://www.huffingtonpost.com/daniel-wagner/al-qaedas-growing-influen_b_5419913. html.

48. Michelle Nichols, "Libya Arms Fueling Conflicts in Syria, Mali and Beyond: UN Experts," Reuters, (April 9, 2013), retrieved from https://www.reuters.com/article/us-libya-arms-un/libya-arms-fueling-conflictsin-syria-mali-and-beyond-u-n-experts-idUSBRE93814Y20130409.

49. Nichols, "Libya Arms Fueling Conflicts in Syria, Mali and Beyond: UN Experts."

50. Zvi Mazel, "ISIS in Sinai: The Libyan Connection," The Jerusalem Post, (February 21, 2017), retrieved from https://www.jpost.com/Middle-East/ISIS-in-Sinai-the-Libyan-connection-482149.

51. Frederic Wehrey, "When the Islamic State Came to Libya," The Atlantic, (February 10, 2018), retrieved from https://www.theatlantic.com/international/archive/2018/02/isis-libya-hiftar-al-qaedasyria/552419/.

52. Pham, "20 Years after the Embassy Bombings: The Long War in Africa."

53. Cilliers, "Violent Islamist Extremism and Terror in Africa," p. 27.

54. Cilliers, "Violent Islamist Extremism and Terror in Africa."

55. Cilliers, "Violent Islamist Extremism and Terror in Africa." 